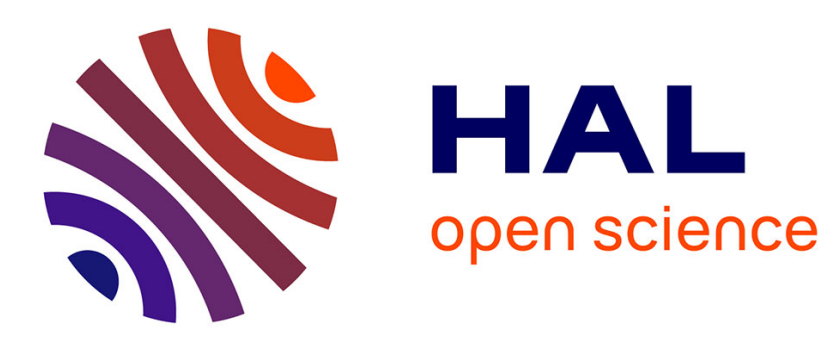

\title{
Incarnation and the dynamics of medical promises: DHEA as a fountain of youth hormone
}

\author{
Boris Hauray, Sébastien Dalgalarrondo
}

\section{To cite this version:}

Boris Hauray, Sébastien Dalgalarrondo. Incarnation and the dynamics of medical promises: DHEA as a fountain of youth hormone. Health, 2018, 23 (6), pp.639-655. 10.1177/1363459318769437 . halshs-02437749

\author{
HAL Id: halshs-02437749 \\ https://shs.hal.science/halshs-02437749
}

Submitted on 13 Jan 2020

HAL is a multi-disciplinary open access archive for the deposit and dissemination of scientific research documents, whether they are published or not. The documents may come from teaching and research institutions in France or abroad, or from public or private research centers.
L'archive ouverte pluridisciplinaire HAL, est destinée au dépôt et à la diffusion de documents scientifiques de niveau recherche, publiés ou non, émanant des établissements d'enseignement et de recherche français ou étrangers, des laboratoires publics ou privés. 


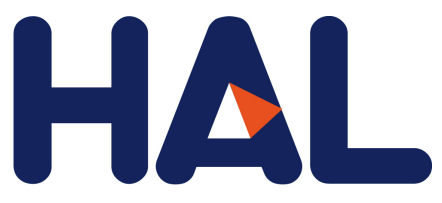

archives-ouvertes

\title{
Incarnation and the dynamics of medical promises: DHEA as a fountain of youth hormone
}

\author{
Boris Hauray, Sébastien Dalgalarrondo
}

\section{To cite this version:}

Boris Hauray, Sébastien Dalgalarrondo. Incarnation and the dynamics of medical promises: DHEA as a fountain of youth hormone. Health, SAGE Publications, 2018, 23 (6), pp.639-655. 10.1177/1363459318769437. halshs-02437749

\section{HAL Id: halshs-02437749 https://halshs.archives-ouvertes.fr/halshs-02437749}

Submitted on 13 Jan 2020

HAL is a multi-disciplinary open access archive for the deposit and dissemination of scientific research documents, whether they are published or not. The documents may come from teaching and research institutions in France or abroad, or from public or private research centers.
L'archive ouverte pluridisciplinaire HAL, est destinée au dépôt et à la diffusion de documents scientifiques de niveau recherche, publiés ou non, émanant des établissements d'enseignement et de recherche français ou étrangers, des laboratoires publics ou privés. 


\title{
Incarnation and the dynamics of medical promises: DHEA as a fountain of youth hormone
}

\author{
Boris Hauray \\ National Institute of Health and Medical Research (INSERM), France
}

\section{Sébastien Dalgalarrondo}

The National Center for Scientific Research (CNRS), France

\begin{abstract}
For more than a decade, the sociology of hope and expectations has gained growing influence in the social studies of health, medicine, and healthcare. This literature has stressed the role of representations of the future-through images, metaphors, theories, or visions - in the medical sector and analyzed the translation of these discursive contents into social practices and organizations. This article builds on these results and intends to explore a dimension that has received less attention: the incarnation of medical promises. Looking at the evolving case of a particular molecule, dehydroepiandrosterone (DHEA) - which has been promoted from the mid-1990s onwards as a "fountain of youth" pill-, we emphasize that testimonies by and portrayals of those who are undergoing a treatment with uncertain risks and benefits, and representations of their bodies in the media, can play a key role in the performativity of a medical promise. We analyze this incarnation as a specific "form of veridiction" and stress its normative dimension. This leads us to underline how evidence-based medicine and experiential knowledge-which are often analyzed as two opposite sources of information-can intricate and give rise to the same incarnation dynamics.
\end{abstract}

\section{Keywords}

anti-aging, incarnation, medicines, promise, self-experimentation

\section{Corresponding author:}

Boris Hauray, National Institute of Health and Medical Research (INSERM), IRIS—EHESS, 54 Boulevard Raspail, 75006 Paris, France.

Email: hauray@ehess.fr 


\section{Introduction}

In the mid-1990s, scientific data about the anti-aging properties of a hormone, dehydroepiandrosterone (DHEA), unleashed a veritable social phenomenon, pushing millions of patients worldwide to take a little-understood molecule with potential important side effects. In France more specifically, the media described a "crazy enthusiasm for DHEA"1 with thousands of people initiating rejuvenating treatments, often with the encouragement of their physicians and pharmacists. Health institutions (the French Medical Association, the French Council of Pharmacists, the French Medicines Agency) reacted in 2001 to this "uncontrolled" clinical experimentation, underlining both the risks of hormonal treatments and the lack of proof concerning the alleged properties of DHEA supplements. In the following months, the DHEA anti-aging effect came to be represented as a false hope and progressively disappeared from the sphere of the traditional media. One could have thought that this medical promise would eventually fade away, but in France, as in several other countries (Rutkowski et al., 2014), DHEA is still commonly used to resist some of the effects of aging. How can we understand the success and survival of this medical promise among members of the general public? What does this trajectory tell us about the dynamics of "medical promises," which play a crucial role in medicalization processes, particularly in the field of aging (Mykytyn, 2008; Vincent, 2006)?

The promise of slowing down, stopping, or even reversing the aging process is, in a sense, medicine's hyper-promise and the ultimate victory of science over human nature. It has long-standing roots, and new "solutions" have emerged regularly in the public and scientific space (Haber, 2004). Since the mid-1980s, in a context marked by "ideals of timeless living and growing older unburdened by the signs of aging" (Katz, 2002), this promise has intensified, diversified (Vincent, 2006) and it has influenced how people "interpret" their aging process (Dalgalarrondo and Hauray, 2015a). At least, three dynamics can be distinguished: (a) the development and institutionalization of fundamental research on the aging process and toward life-extending strategies (Fishman et al., 2008), (b) the emergence of an "anti-aging medicine" movement from the early 1990s (Mykytyn, 2010), (c) the pathologization and medicalization of several effects of the aging process, such as wrinkles, hair loss, erectile dysfunction (Conrad, 2007). As a consequence, researchers claims on DHEA anti-aging properties appeared in a society that was overwhelmingly permeable to this hope. More specifically, journalists' well-known tendency to sensationalize the significance of research results (Nelkin, 1987) - for example, through the rhetoric of the "great breakthrough" and the widespread use of metaphors such as "the fountain of youth pill" - and promoters' complementary efforts to legitimize this contested avenue of research were influential in the dynamics of the DHEA promise (Dalgalarrondo and Hauray, 2015b). However, underlying the existence of a favorable normative environment and exhibiting the content of promissory claims (metaphors, scenarios, etc.) is not sufficient to explain the success of a medical promise. We need to better understand the performativity of these discourses and their capacity to change people's beliefs and behavior.

We hypothesize in this article that what we call "the incarnation" of this medical promise, the fact that it was spread through testimonies by and portrayals of professionals and patients who had put their own body at risk (as opposed to impersonal and 
external promissory discourses), was determinant. While stressing the central place of this incarnation in the anti-aging field, we seek to specify in this article the characteristics of this form of discourse and explain its capacity of influence. Our analysis thus seeks to contribute to the growing body of literature that has emerged on the role of hope or expectations in health, medicine, and healthcare (Petersen, 2015).

Probably because the most well-known world specialist of DHEA was French, the molecule received considerable attention in that country, and this article will focus on the French case. It is based on a study of the main scientific publications concerning DHEA and aging between 1960 and $2014(\mathrm{n}=64)$ and content analysis of articles in the main daily $(n=6)$ and weekly newspapers $(n=2)$ in France that mentioned DHEA between 1980 and 2014 (280 articles). In order to understand how a promise is presented to the general public, we also conducted an analysis of how French television programs dealt with DHEA between 1995 and 2010 in the three main TV channels (TF1, France 2, and France 3), looking both at what was said and what was shown $(\mathrm{n}=38)$. We also analyzed online discussions about DHEA in a forum of the most popular health website in France (doctissimo.com) between 2002 and 2015 (342 threads).

The first section of this article presents the role of incarnation in the dynamics of medical promise and the main characteristics of this form of discourse. The second section summarizes the history of the DHEA anti-aging promise. The following two sections analyze professionals' and patients' incarnations of the DHEA promise and their effects. The final section shows that, following the disappearance of this promise in traditional media, online health forums constituted new public places where these logics of incarnation persisted.

\section{On incarnation and medical promise}

Promises, taken in the widest sense to include both positive declarations and expectations about the future (Rubin, 2008), have, for some time, been a fruitful field of inquiry in the study of biomedicine (Nelkin, 1987). However, for more than a decade and notably under the banner of a nascent "sociology of hope" (Petersen and Wilkinson, 2015) and of a developing "sociology of expectations" (Borup et al., 2006), the role played by anticipated futures in health, medicine, and healthcare has attracted growing attention from the social sciences. Emphasis has been put on images, metaphors, or on futuristic scenarios/visions publicly promoted by scientists, doctors, journalists, or firms (Brown, 2000; Hedgecoe and Martin, 2003; Petersen and Seear, 2011; Selin, 2007). The emotional evocation of potential beneficiaries of new treatments has also been underlined (Brown, 2003; Kitzinger and Williams, 2005). Several works have emphasized the performative nature of these hopes and analyzed the translation of promissory discourses "into a heterogeneous set of professional practices, social organizations, and physical artifacts" (Hedgecoe and Martin, 2003: 331). For example, in his analysis of "hope scales" used to measure the emotional states of cancer patients, Brown (2015) has claimed that "It has become important to recognize the extent to which hope has become a vector for the embodiment of, and indeed the embodied reproductivity of, promissory futures." Petersen (2015) has stressed that discourses of hope "are intimately connected to the workings of politics and power" and that they 
shape a "political economy of hope" (Novas, 2006; Petersen, 2015) linking patients, clinicians, researchers, governement, and firms. Moreira and Palladino (2005) have distinguished two logics in contemporary biomedicine: the "regime of truth" that "entails an investment in what is positively known" and the "regime of hope" "characterized by the view that new and better treatments are always about to come" (Moreira and Palladino, 2005), while Brown (2007) has underlined that "Hopes articulate with future values, truths with a present regime of facts."

Building on these important results, this article intends to focus on the incarnation of medical promises. Through this term, we want to point to the testimonies by and portrayals of those who have experienced a new therapy, but also to the representations of their bodies (notably in the media). Incarnation is thus to be understood as a modality of discourse on new therapies and more precisely to use a Foucauldian notion (Foucault, 2009) as a mode of veridiction: incarnation is a mode of truth-telling on health interventions that can be distinguished from other discourses presenting things as true (for example impersonal discourses based on evidence-based medicine (EBM) results or general discourses on the potential of an innovation). We suggest that, in situation of uncertainty as regards the risks and benefits of a therapy, "incarnation" can have an important influence on people's will to experiment. These experimentations will then produce new knowledge and trigger new "incarnations." Incarnation can thus play a crucial role in the performativity of hope discourses.

We prefer to use the term "incarnation" rather than "embodiment," as incarnation refers more exclusively to a living body (incarnation comes from the Latin word incarnare: in- "caro," to make into flesh or to be made flesh), whereas embodiment has been used to analyze how expectations are "inscribed" into objects and machines (Borup et al., 2006). Moreover, its religious etymology is of interest here (in Christian theology, the doctrine of Incarnation holds that through Jesus, "the Word was made flesh" (John 1:14)). Petersen (2015) notes that "the meanings of 'hope' in health and healthcare closely parallel the meanings of "hope' in the sphere of religion." The notions of "expectation," "hope," and "promise" have all been used in the social science literature and have closed meanings. In this article, we refer to "promises" rather than to "expectations," as we want to focus on positive anticipatory discourses. Moreover, the notion of "promise" problematizes the relationships between the production and the reception of anticipatory discourses, whereas the notion of "hope" has been used to underline a shared belief between patients, doctors, and pharmaceuticals companies (Novas, 2006).

Four characteristics of "incarnation" can be analytically distinguished to explain its capacity to impact beliefs and behaviors: (a) it mobilizes individual stories, (b) it relies on individuals' own experimentation of the effects of the therapy, (c) it depicts ability to do things (as opposed to the physiological/biological effects of the therapy), (d) it often involves displaying bodies. First, even if the veracity of testimonies, whether on the Internet or on television, can always be questioned, incarnation allows storytelling, and there is, as suggested by epidemiologist Newman (2003), a "power of stories over statistics": "the brains of human beings seem built to process stories better than other forms of input," and a testimony "enables a connection with the listener or reader beyond what would be possible if the story were recounted by a dispassionate observer" (Newman, 2003). Second, a central issue in the use of new medical treatments is their potential 
adverse effects. As a consequence, the fact that those (patients, but also doctors see below) who are speaking in favor of a treatment have put their own bodies at risk is crucial in the credibility of their discourse and in its performativity. In this regard, the incarnation of medical promises sheds light on "parrhesia." As underlined by Foucault (2009) in his analysis of the different forms of veridiction in Antiquity, the specificity of this mode of truth-speaking (the three other modes identified by Foucault are prophecy, tekhne, and wisdom) is that parrhesiasts speak in their own names, about an actual and concrete situation, and that the effectiveness of their discourse relies on the fact that they stake their own lives on what they are saying. Third, compared to the diffusion of figures for example, incarnation produces knowledge of a specific epistemic value. It allows a connection between the two dimensions of life identified by the French philosopher Canguilhem (1966): le vivant (the living) and le vécu (the lived), two grammatical forms of the verb vivre (to live). The effects of treatments are not only represented and analyzed in their biological dimension, through their effects on specific pathologies but also as a transformation of people's lived experience, for example a renewed ability to do things. Fourth, incarnated discourses often involve the representation and staging of cured (or in our case "rejuvenated") bodies, and these bodies may appear to many people as tangible and unquestionable proof. These different characteristics draw attention to the fact that promissory discourses on medical innovations have a strong normative dimension (Hedgecoe and Martin, 2003; Kitzinger and Williams, 2005): discourses which aim at presenting some therapeutics claims as true also participate to the construction of these treatments as desirable and ethical. In this regards, "incarnation," which involves real and identifiable persons, produces discourses that articulate "facts" and "values." It disseminates a "bioethics in action," and patients' identity or social position may participate in the development of a medical practice (Petersen, 2015). For example, in the "Age of Anxiety," Tone (2012) suggested that Milton Berle, a US television superstar, fostered the rise of the "tranquilizer culture" in the 1950s by frequently referring during his show to the wonderful effects the first prescription tranquilizer (Miltown) had on him.

Traditional media (television and press) have for some time been a powerful vehicle for the representation of recovering/cured bodies and for patients' narratives on the efficacy of new treatments (Seale, 2003). For several years now, the Internet has become another crucial place for the production and diffusion of "experiential knowledge" on health (Conrad et al., 2015). Petersen and Seear (2011) have, for example, shown that patient testimonials are widely used in websites offering stem-cell treatment and they underlined their role in the "political economy of hope." It is worth noting that the DHEA case also involves a very interesting — albeit more specific — form of incarnation: a large number of DHEA promoters (scientists and doctors) also acknowledged taking this experimental product themselves. For potential consumers, but also for their colleagues or public decision-makers, this admission showed both the sincerity of their position and the strength of their belief in the molecule. Given their status and personal qualities ("not looking their age," dynamic), they acted as "living and vital testimony" to their promise. Anti-aging medicine promoters often allude to this "community of promise"-in which patients and doctors share the same innovative practices - to defend the validity and sincerity of their approach. In a personal interview, R. Klatz, Founder and President of the American Academy of Anti-Aging Medicine (A4M), emphasized that A4M was "the 
only medical society in history where $100 \%$ of its members are patients themselves, as no doctor (who) becomes involved in anti-aging medicine ... would not treat himself/ herself too" (Stuckelberger, 2008).

\section{A short history of the DHEA promise}

DHEA was isolated by A. Butenandt and H. Dannenbau in 1934 and extracted from human plasma in 1954. In 1960, French doctor and researcher E.-E. Baulieu proved that the suprarenal glands secreted DHEA's sulfate ester (DHEA-S) and that there was an inter-conversion between the two molecules, that is, they naturally converted from one to the other. During the 1960s, the metabolism of DHEA was studied: it was shown that DHEA is the most abundant circulating steroid hormone in the human body and that its concentration in the blood declined steadily with age. On the basis of this fundamental knowledge, studies were carried out on administering high doses of DHEA to animals. From the mid-1980s, this pre-clinical research led to a growing body of publications which suggested that by compensating the DHEA decline in aging adults, it could be possible to counteract defects associated with aging, including osteoporosis, loss of memory, weakening of the immune system, weight gain, and cholesterol. As concerns human subjects, in 1986, an epidemiological study published in the New England Journal of Medicine by a team from San Diego showed a link between low levels of DHEA in 250 men (between 50 and 79) and a higher mortality rate, particularly cardiovascular mortality (Barrett-Connor et al., 1986). This same team (led by Samuel Yen) carried out clinical research on 13 men and 17 women, between 40 and 70 years of age, testing doses of $50 \mathrm{mg}$ of DHEA against placebo over a 6-month period. The team published results in 1994 in the Journal of Clinical Endocrinology and Metabolism, the world's leading peerreviewed journal in the field. They showed an improvement of physical and psychological well-being in both genders.

The second half of the 1990s was a period during which this promise became stronger, under the banners of S. Yen in the United States and E.-E. Baulieu in Europe, who decided to revive research on "his" molecule. In France, the first article to present the anti-aging promise of DHEA in detail and for the general public was a special report published in January 1995 in one of the main weekly news magazines (Le Point). In its introduction, the article claimed that DHEA "will perhaps afford us, in a few years, an old age that is partly free from the difficulties that are the curse of senescence."2 This long article was taken up by other papers but also was discussed on the evening news of the main French television channels (TF1, France 2, and France 3). During the following months, references to the "fountain of youth" abounded not only in the general press but also in scientific journals. In March 1998, Professors E.-E. Baulieu and F. Forette launched the world's first large-scale study — named "DHEAge" — that aimed at evaluating the benefits of a daily dose of DHEA in elderly subjects. Over the course of a year, 280 subjects of both sexes aged between 60 and 79 and presenting no particular pathologies took either DHEA or a placebo. As well as testing that the drug was innocuous, the study's hypotheses regarding the efficacy of the treatment were improvement of general well-being, improvement of intellectual performance, stimulation of the immune system, increase in muscle strength and preservation of bone mass, and decrease of vascular and 
cutaneous aging. While waiting for results, the French press continued to spread the promises linked to DHEA. The results were finally published in 2000 in the American journal Proceedings of the National Academy of Sciences (Baulieu et al., 2000). DHEA appeared to be without short-term danger, but the statistically proven benefits remained disappointing in comparison with the hope placed in the molecule. The study only showed a decrease in bone deterioration (in few bone areas) and improvement in skin state and libido. These benefits mostly concerned a sub-population: women over the age of 70. Although the media did allude to certain limits of the results of the DHEAge study, they mainly used the rhetoric of great scientific discoveries (Dalgalarrondo and Hauray, 2015b). The daily newspaper Libération, for example, published an article under the title "A new lease on life for the youth hormone," which stated "The first results of a long study show that DHEA improves the state of elderly people in good health."3 On French television, the information was taken up in the evening news. The question of it being unavailable in France (except for people buying it abroad or on the Internet), particularly in contrast with the United States where it had been widely sold as a dietary supplement since 1994, became the main issue in the following months. In 2001, press coverage increased even further. In fact, it was found that the molecule had an ambiguous legal status: while the unauthorized product could not be sold as a pharmaceutical specialty, the raw material was not listed among banned substances and could be purchased by pharmacists who could then make extemporaneous (magistral) preparations if a doctor wrote a prescription. Thus, French distribution networks for DHEA were established from the end of 2000 and more people (and of different ages) started DHEA supplementation. In light of the enthusiasm created by DHEA, the Ordre des médecins (the French Medical Association) and French Council of Pharmacists reacted in spring 2001 and warned their members about the risks of the product and their personal responsibility while prescribing and distributing it. The French medicines agency published a report in which experts were severe in their judgments about the DHEAge study, especially the very limited positive effects of the therapy and suggested they could be "coincidental given the multitude of parameters studied." The Minister for Health also declared on TV news that "None of the alleged effects of DHEA on aging have been demonstrated to date" (TF1, 10 July 2001) but that "rather than banning the dream," he would reinforce public control on the distribution of the product. From then on, press coverage of the molecule was more negative and steadily declined. In April 2002, the influential French independent medical journal Prescrire published an article entitled "DHEA, the last elixir" which stated there was "no scientific reason to prescribe DHEA for any purpose whatsoever." 4 The years that ensued were no more positive for the anti-aging properties of the molecule from a scientific point of view, and an editorial of the NEJM "Aging and Fountain-of-Youth Hormones" claimed the debate was now over (Stewart, 2006). These medical articles were reported in the French general press. Nevertheless, and in spite of this cycle of hype and disappointment, the consumption of DHEA did not disappear during the following years. In 2008, the French Medical Drug Agency still estimated French DHEA consumers at 130,000, a figure that did not include Internet sales (Le Fur, 2010), which could probably be considered to be the majority. Some media reported in the mid2000 s that there could be more than 500,000 consumers. ${ }^{5}$ In the next sections, we stress the role of the incarnation of promise in these dynamics. 


\section{From credibility to parrhesia}

The success of the DHEA promise was of course fostered by the scientific credibility of its main promoter, E.-E Baulieu who was then professor in the prestigious Collège de France and world famous for having invented the controversial abortion pill (RU486). The Associated Press report noted that "Far from a wishful fantasy, DHEA is the brainchild of Dr. Emile-Etienne Baulieu, esteemed inventor of the RU486 abortion pill, which has withstood the test of time and controversy"6 and a Reuters report underlined that E.-E. Baulieu was "a winner of the U.S. Lasker medicine prize." Research on aging has long suffered from the status of a "forbidden science" (Fishman et al., 2008) and making known E.-E. Baulieu's qualifications as a legitimate biomedical researcher were instrumental in the boundary-work (Gieryn, 1983) necessary to present the DHEA promise as sound science. The first newspaper article to praise DHEA in France clearly articulated this dimension:

The person preparing this magic potion for us is not one of those quacks with a silver tongue, but rather a cautious man, a true scientist, both doctor and chemist, and one of France's greatest researchers. ${ }^{8}$

But the credibility of Baulieu's promise was not based solely on his "reputational capital" (Latour and Woolgar, 1986). In his masterpiece "A Social History of Truth," Shapin (1994) has analyzed the closed relationships between R. Boyle's status as a gentleman and his ability to be regarded as a faithful interpreter of nature. In the DHEA case, the media engaged in storytelling and underlined several properties of Baulieu's career and personality that were congruent with the discovery of an anti-aging treatment, that is, an exceptional breakthrough, a long-standing dream of humanity that could lead to profound social transformation. They evoked Baulieu's role in the French resistance movement as a communist activist during the Second World War, his public involvement in favor of women's rights in Europe and in the United States, and his upbeat and fighting attitude and aging being his "new enemy." 9 They also stressed his idealistic stance, his passion for research, and his lack of interest in money. Portrayals and interviews also depicted his freedom of thought and even his artistic sensibility (newspapers noted that he was a friend of Andy Warhol and of Niki de Saint-Phalle). These references underlined Baulieu's high moral values, implying that he could be trusted, but they also suggested he was not merely a scientist like the others, but a genuine creator.

An even more direct incarnation of the DHEA promise by E.-E. Baulieu emerged in the media. E.-E. Baulieu, who sang praises to DHEA on television, was a "hyperactive" researcher who was enthusiastically piloting an innovative and ambitious program of research, who was also an attractive man, with no white hair, and yet who was - in 1995 - already 68 years old. In 1995, a journalist claimed " May this molecule bring us to the same physical and mental state as professor Baulieu when we are 68 years old!."10 The same year, Baulieu recognized that he had taken DHEA (but he said he had stopped because the level of the hormone in his blood was good). In 2000, asked once more about his own consumption of DHEA, he said he had just started the treatment again and cautiously claimed that he "feels in better shape." He added "And don't ask me how my libido is doing, it's indiscrete", 11 suggesting a sexual effect. This self-experimentation 
became commonplace in the discussion of DHEA in France, and allusions to Baulieu's incarnation of the DHEA promise continued, even after the properties of DHEA were called into question. For example, in 2007, a portrayal of E.-E. Baulieu in the French newspaper of reference, Le Monde, entitled "Mister Long Life," emphasized that he was still traveling the world at 80 years old to promote his new research "in perfect shape," that he was a "striking example" of successful aging ${ }^{12}$ and that he was taking DHEA. The same year, in an interview in the weekly magazine L'Express, a journalist claimed he was a "living advertisement" for DHEA. ${ }^{13}$ More broadly, the idea that medical doctors and professors or even pharmacists, owing to their privileged access to the molecule, were themselves enjoying the benefits of DHEA, was widespread in the early 2000s. For example, during a Sunday TV show on French public television dedicated to the molecule, a participant claimed: “... all the eminent professors take it and say that it's wonderful" (France 2, 6 May 2001).

This professional incarnation of the promise was not specific to France. In June 1995, a large conference was organized by the New York Academy of Sciences, with the collaboration of the National Institute on Aging, bringing together researchers from all over the world (including E.-E. Baulieu and S. Yen) who were working on the molecule. This conference gave wide media coverage and strong scientific credibility to the link between taking DHEA and fighting aging. During this conference, many researchers and doctors expressed enthusiasm and recounted the effects of taking DHEA themselves. During the large press conference organized following S. Yen's presentation, a journalist asked the doctor if people should start taking DHEA right now, in spite of the potential risks of hormonal treatment. He replied in the affirmative emphasizing that from what he understood, like himself, half the conference participants had been taking it for 4-5 years (Fahy, 1995). Professor W. Regelson, a medical oncologist and a leading researcher in the field of aging, was interviewed in connection with the conference in the magazine The Sciences:

The thing that I've noticed," William Regelson said, settling into his chair, "is a return of morning erections." The immunologist across the table nodded between mouthfuls ... "I mean, I felt like I was twenty years old again. (Bilger, 1995: 26)

In 1997, he published a best seller entitled The Superhormone Promise: Nature's Antidote to Aging in which he stressed,

I have spent more than twenty years researching DHEA ... the last ten years I have been taking it myself .... My wife, Sylvia, has taken it for nearly eighteen years. From my own personal experience, I can attest that the benefits can be felt almost immediately. (Regelson and Colman, 1997)

\section{Patients' incarnation of DHEA promise}

Prosser (2010) notes that media stories assign medicines into two opposite categories: "marvelous medicines" or "dangerous drugs." Furthermore, health news in the media tend to rely heavily on individual stories, with which their audience can identify (Seale, 2003). Not surprisingly, living and concrete testimonies of patients concerning the benefits of DHEA and images of their bodies supported the majority of the reports and articles on the DHEA. A large proportion of these patients were the very participants of the 
DHEAge trial and reports usually summarized quickly the results of the study but paid much more attention to their experiential knowledge and to the abilities of their rejuvenated bodies. This patient incarnation disseminated a thicker representation (Ryle, 1968) of the DHEA effects: it shed light on the lived experience of users (as opposed to the biological effects put forward on skin, bones, and libido) and showed their bodies in actions. As a consequence, this incarnation redefined the properties of the molecule, exhibited situations in which people could project themselves, and articulated "facts" and "values" (e.g. through the use of a thick concept like "vibrant" to describe a woman). We even suggest that questions of distinction and imitation (Bourdieu, 1979) were influential. The desirable nature of taking DHEA was built upon DHEA therapy first being practiced by "privileged" people: celebrities, wealthy Americans, people traveling abroad, and the "happy few" participants of the DHEAge study.

One of the first patients to testify on French television about taking DHEA was Françoise Giroud, a much-respected journalist, writer, and politician. She had been editor in chief of the main French woman's magazine after the Second World War (Elle), co-founder of one of the most important weekly political magazines (l'Express), Minister of State for Women's Affairs (1974-1976) and Culture (1976-1977). Aged 80 in 1996, she was presenting her latest book on the public channel France 2 when she was asked about how she was living her own aging process. She declared, "I am tired of aging, I want it to stop" and in the conversation, she admitted she had begun DHEA treatment. The journalist immediately replied, "Oh, this is why you look so radiant" (France 2, 7 July 1996). Several other emblematic celebrities were reported to take DHEA. In 2000, whereas DHEA was still unavailable to the general public. Johnny Hallyday, probably France's most famous singer (he was already a star in the 1960s), known for his strong presence on stage, announced he was following a "course of rejuvenation therapy" by taking DHEA: "I don't want to retire, it does not exist in my job." 14 On the website of a regional trade union of pharmacists, a member wrote in 2001: "the smartest or those in the best positions do not hide, by the way, their consumption (of $D H E A$ ), starting with E.-E. Baulieu himself or Johnny Hallyday, the old rocker who fights against his wrinkles." 15

Before DHEA was widely distributed in France, the DHEA promise was also incarnated by the French living in the United States or by American consumers. For example, an article in the newspaper Le Progrès explained in 1998 that in the United States "Consumers are numerous and there is no shortage of positive feedback" and described the case of a French pianist living in San Diego: "She certifies that, since she has taken it, she has regained the finger flexibility she had lost because of her arthritis. But as soon as she stops, the pains return."16 The most well-known documentary program in France (Envoyé Spécial, somewhat similar to CBS' 60 Minutes or the BBC's Panorama) ran a report on hormonal therapies (including DHEA) in the spring of 2000. The topic focused on the delighted patients of a clinic in Palm Springs, the Life Extension Institute, which received 3000 patients per year. The opening scene pictured Bob Jones, an 80-year-old tanned, good-looking, retired marketing executive, running bare-chested in the mountains, with a song in the background that went "I'm free to do what I want, any old time." He later explained that hormonal therapy had improved his physical strength, his libido, and his hair. 
However, the main vectors of patients' incarnation of the DHEA promise were the participants in the DHEAge trial. Given the publicity surrounding the molecule, the media paid attention to these 280 men and women as soon as they were recruited, reporting their first meeting or their happiness at being part of the study. ${ }^{17}$ When the results of the DHEAge study were published in the spring of 2000, virtually every TV report on the study also involved a testimony from one of these participants and powerful images of his or her rejuvenated body. For example, the public television channel France 3 broadcasted a report showing 74-year-old Suzanne in the swimming pool. She explained,

Since I've been taking it, I feel well and invigorated and I feel like doing things, and I find that extraordinary because a few years ago, I really had to force myself to do things. (France 3, 11 April 2000)

The journalist said that DHEA had given Suzanne the energy to start her sports activities again but also her Russian lessons at the University. After a sequence in which the results of the study were described, the report concluded by underlining that, as DHEA was not marketed in France, "currently no elderly persons can benefit from it." This statement was illustrated by the elderly people calmly talking in a retirement home, some in wheelchairs, an image sharply contrasting with those of Suzanne in a swimsuit. The same day, a volunteer stated on the most-watched news program in France (Le "20 heures," TF1): "Since I started the DHEA protocol, I've stopped having asthma attacks, I don't go to see my doctor anymore, if I didn't look at my date of birth, I'd forget about my age ...." During the following months, these volunteers appeared on several occasions on television. For example in 2001, a report on TF1 portrayed Geneviève, "a vibrant 71-year-old woman" (also a volunteer of the DHEAge trial) and showed her hanging curtains, arms outstretched in equilibrium on a high stepladder (TF1, 12 April 2001). These volunteers were also very much present in the written press, where they concretely described the changes they had experienced. A few volunteers were less enthusiastic, but press articles stated that 240 of the 280 volunteers had asked to continue the treatment after the trial. It is worth noting that these volunteers were described as the "most posh French cohort": 18 "... they are in most cases very dynamic people, very concerned about their aging. A lot are intellectually and socially privileged." 19 said an investigator.

\section{The role of online forums in the survival of the promise}

Following the political and medical counter-offensive against the product in mid-2001, the DHEA promise was progressively delegitimized in traditional media. However, at the same time, health-specialized websites developed in France. The most popular health website in France (doctissimo.com) opened in 2000, but its forums (forum.doctissimo.fr) developed starting in 2002 and one of them was dedicated to "DHEA and miracle pills." Health websites now represent a major place where people look for information on their conditions and on therapies. As concerns DHEA, most people participated in the forum as "technology consumers" not as "expert patients" (Fox and Ward, 2006): even though some sought or delivered specific information (e.g. on the risks of interactions with other drugs, on the need to measure one's level of DHEA before starting the treatment or on 
suspected side effects), few references were made to external sources of information, and participants primarily shared information on their own health state, on their willingness to test the molecule or on ways to obtain some, and on the effects (or lack of effects) of DHEA on their bodies and lives. Our aim in this section is to show that, after DHEA disappeared from TV and the press, these incarnations perpetuated several dynamics identified in the previous two sections.

In line with previous studies that have shown that people consulting online health forums are first and foremost seeking experiential knowledge (Thoër and Lévy, 2012), numerous topics such as "DHEA, I wait for your testimonies," or "What do you think of DHEA?" were created from 2002 to the present, even though interest in the molecule decreased after 2008. Some consumers said that DHEA had not worked for them, underlined its risks (most notably the risk of cancer) or described the side effects they had experienced (hair loss, oily skin, etc.). A large number of testimonies were nevertheless very positive. People notably explained that their libido and skin condition had improved or that their joint pains had decreased. But, as in the TV testimonials, and beyond biological effects, participants described broader changes in their life (in their activities, their couple, etc.), in their body, and in their relation to it: they felt "ten years younger," they were "full of energy," "less stressed," and "eager for life." For example, in one of the first threads on DHEA on doctissimo, a woman claimed,

This is not a medical opinion, but one from a 72 year old user who has taken DHEA for one year now. Never tired, with boundless energy, numerous activities and always with new projects to start. General opinion is I don't look my age. (13 February 2002)

It is worth noting that some of these online self-expressions were sometimes explicitly framed as self-experimentations (Carah et al., 2017) and even imitated a medical case study. For example, in a discussion thread called "DHEA-Started 11.04.2007," a woman explained that as a consequence of feeling tired, "rusty," with no libido, and depressed: "I will embark on the adventure and I agree to serve as a guinea pig." She said she would make a report every week. After 2 weeks, she noted "Today D+15 ... I feel really very well: much more zen - a little euphoric" and after 1 month: "my libido is coming back. My husband is a happy man." In this thread, several consumers compared their evolving positive or negative/lack of effets over several weeks.

Several participants complained about their general practitioner's refusal to prescribe DHEA. But, as in the traditional media, the fact that doctors were themselves taking DHEA was often mentioned: "a doctor and friend of mine who uses DHEA has noticed very encouraging effects" (27 February 2008); "my doctor has taken it for seven years and there is no need to tell you the great results" (04 December 2010). Some participants purporting to be doctors also described their own use of the molecule and their threads were very popular: "I am a doctor and I have taken DHEA for two years. I am a 47 year old woman, I purchased the first year of treatment in the USA [...] I have felt the beneficial effects on my skin, $[\ldots]$ on my sleep, $[\ldots]$ and also on my sexuality; there is no comparison" (08 February 2003).

It is impossible to measure the real impact of these narratives. Nevertheless, some topics were read more than 30,000 times, some received several hundred answers. 
Furthermore, we can observe that the redefinition of the criteria used to describe and evaluate the effects of molecule induced by the experiential knowledge on DHEA was influential. For example, several participants alluded to their problems in life, their depressed state or lack of energy as motivation for testing the product. The capacity for people considering the DHEA promise to have intimate and direct exchanges with usersparrhesiasts also reinforced their will to experiment. Finally, the fact that forum enabled asynchronous exchanges (some threads created in 2003 were still active in 2008) fostered the survival of the incarnation promise years after the hype was over.

\section{Conclusion}

In May 1889, on the basis of his work on the suprarenal glands, C.E. Brown-Séquard, one of the founders of endocrinology and the successor to Claude Bernard at the Collège de France, injected himself with extracts from the testicles of guinea pigs and dogs. Then aged 72, he said the injections had made him feel 30 years younger (physical strength, intellectual capacity, and sexual potency were the main benefits). This self-experimentation was published in The Lancet (Brown-Sequard, 1889) and was taken up by scientific journals and the general press alike. During the following years, he treated numerous colleagues and celebrities (L. Pasteur, E. Zola), and the accounts of delighted patients fostered the dissemination of his therapies on a global scale (Celestin, 2013). During the 20th century, with the rise of the randomized controlled clinical trial as the gold standard for studying therapeutics in medicine (Marks, 1997; Timmermans and Berg, 2003), the methods and norms for producing scientific evidence have radically evolved. But the publicization of biomedical research results, of figures, even when it is combined with promissory discourses on the future of a technology, is not the only driver of the diffusion of medical promises. In a context marked by high hopes in biomedicine and biotechnology, by the rapid circulation of therapeutic compounds and by the diversification of information sources concerning them, this article has sought to underline that the incarnation of medical promises still plays an important role in their construction and dissemination.

The main aim of this article was to analyze "incarnation" as a specific form of discourse, explaining the capacity of a medical promise to change people's beliefs and behaviors. We shed light on four main features of this "truth-telling": the connection of medical information with personal stories; the influence of self-experimentation as a form of parrhesia; the representation of the lived experience of users and its impact on the mere definition (and evaluation) of the treatment effects; and the showing of bodies. We claimed that the incarnation of the DHEA promise had a key influence on people's "will to experiment" and that these experimentations triggered new incarnation dynamics that stabilized the promise even when it was attacked. We showed that both professionals and patients have incarnated the DHEA promise. During the rise of the promise, scientists' self-experimentation was particularly influential. First, it established their "truth-telling": as parrhesiasts, they had put their own life at risk and lived in accordance with their discourse. Second, with their appearance and lives being consistent with the DHEA promise (to remain young, healthy, and active), this self-experimentation produced an early demonstration of the efficacy of DHEA supplements. It also contributed to the survival of the promise: being convinced by their own experience, these 
professionals continued to defend the product when it was called into question. We showed that users' incarnation was also decisive in the performativity of the DHEA promise. Their incarnations emphasized the "lived experience" of taking DHEA, which appeared as a molecule for broadly improving older persons" "well-being" and not just as a pill for treating specific biological age-related problems. They referred to activities, situations, and self-reflections into which potential users could project themselves. During the period in which DHEA attracted a lot of public attention, the very participants of the main randomized clinical run on DHEA played a major role in this process. This fact forcefully underlines that EBM, which is promoted as a "technology of distance" (Porter, 1995), also produces experiential evidence that contributes to the political economy of hope (Novas, 2006; Petersen, 2015). After 2002, when the DHEA disappeared from TV and the press, online forums emerged as new places where the patient (and even the professional) incarnations of the DHEA promise could develop. We stressed several specificities of this phenomenon: direct and intimate exchanges between parrhesiasts and potential users, the fact that users more explicitly presented their experience as the production of new knowledge, the capacity to have asynchronous exchanges. This informal, lay and public experimentation seems to be a neverending story. For example, in 2016, a man declared in a forum on doctissimo that, as it was impossible to have a definitive answer to whether DHEA was effective or not, he will test it and give his own weekly accounts of its effects.

The merging of "facts" and "values" in the incarnation of a medical promise is a dimension that deserves to be emphasized (Brown, 2007; Moreira and Palladino, 2005). Discourses which aimed at demonstrating the positive effects of the molecule also constructed this treatment as something desirable and ethical. During the inception of the promise and given the ambiguous moral status of an anti-aging treatment, the fact that renowned researcher, doctors, pharmacists, and celebrities publicly admitted they used the molecule legitimated DHEA as a true medicine rather than an ethically suspect enhancement aimed at creating "supermen or superwomen." It also fostered the transfer of social status from persons to medication and triggered imitation processes. After the promise ceased to be promoted by traditional media, and even though participants were not promoting an alternative sense of "health" - as in the pro-ana community studied by Fox et al. (2005) — online forums served as a source where users or potential users could reassure themselves concerning the legitimacy of their motives to engage in anti-aging therapy.

In spite of the DHEA promise, anti-aging medicine has not developed in France as strongly as it has in the United States (Fishman et al., 2008; Mykytyn, 2010). However, one can hypothesize that the incarnation of the DHEA promise, which linked an antiaging pill to one of the most famous French scientists and disseminated the representation of aging as a condition that could - and in fact should - be targeted by modern medicine, has had noteworthy effects on the medicalization of aging in French society.

\section{Declaration of Conflicting Interests}

The author(s) declared no potential conflicts of interest with respect to the research, authorship,and/ or publication of this article. 


\section{Funding}

The author(s) received no financial support for the research, authorship, and/or publication of this article.

\section{Notes}

1. Le Point, 6 juillet 2001.

2. Le Point, 7 janvier 1995.

3. Libération, 12 avril 2000.

4. Prescrire, 1 avril 2002.

5. Libération, 20 octobre 2006.

6. Associated Press, 11 janvier 1995.

7. Reuters, 8 janvier 1995.

8. Le Point, 7 janvier 1995.

9. Libération, 17 janvier 1995.

10. Sud Ouest, 5 mars 1995.

11. Libération, 21 novembre 2000.

12. Le Monde, 17 août 2007.

13. L'Express, 6 septembre 2007.

14. Sud Ouest, 1 juin 2000.

15. http://www.pharma68.fr/articles/lesfili.htm

16. Le Progrès, 16 janvier 1998.

17. La Croix, 29 octobre 1998.

18. Le Monde, 17 mars 2001.

19. http://www.lanutrition.fr/communaute/opinions/interviews/letude-dheage-du-pr-etienneemile-baulieu.html

\section{References}

Barrett-Connor E, Khaw KT and Yen SS (1986) A prospective study of dehydroepiandrosterone sulfate, mortality, and cardiovascular disease. New England Journal of Medicine 315(24): $1519-1524$.

Baulieu E-E, Thomas G, Legrain S, et al. (2000) Dehydroepiandrosterone (DHEA), DHEA sulfate, and aging: Contribution of the DHEAge Study to a sociobiomedical issue. Proceedings of the National Academy of Sciences of the United States of America 97(8): 4279-4284.

Bilger B (1995) Forever young (dehydroepiandrosterone and aging). Sciences 35(5): 26-31.

Borup M, Brown N, Konrad K, et al. (2006) The sociology of expectations in science and technology. Technology Analysis \& Strategic Management 18(3-4): 285-298.

Bourdieu P (1979) La Distinction. Paris: Editions de Minuit.

Brown N (2000) Organising/disorganising the breakthrough motif: Dolly the cloned ewe meets Astrid the hybrid pig. In: Brown N, Rappert B and Webster A (eds) Contested Futures: A Sociology of Prospective Techno-Science. Aldershot: Ashgate, pp. 87-108.

Brown N (2003) Hope against hype: Accountability in Biopasts, presents and futures. Science Studies 16(2): 3-21.

Brown N (2007) Shifting tenses: Reconnecting regimes of truth and hope. Configurations 13(3): $331-355$.

Brown N (2015) Metrics of hope: Disciplining affect in oncology. Health 19(2): 119-136.

Brown-Sequard CE (1889) The effects produced on man by subcutaneous injections of liquid obtained from the testicles of animals. The Lancet 134(3438): 105-107. 
Canguilhem G (1966) Le concept et la vie. Revue Philosophique De Louvain 64(82): 193-223.

Carah N, Meurk C and Angus D (2017) Online self-expression and experimentation as 'reflectivism': Using text analytics to examine the participatory forum Hello Sunday Morning. Health 21(2): 119-135.

Celestin LC (2013) Charles-Edouard Brown-Séquard: The Biography of a Tormented Genius. London: Springer.

Conrad P (2007) The Medicalization of Society. Baltimore: Johns Hopkins University Press.

Conrad P, Bandini J and Vasquez A (2015) Illness and the Internet: From private to public experience. Health 20(1): 22-32.

Dalgalarrondo S and Hauray B (2015a) Interpréter son vieillissement. Gérontologie et Société 37(148): 23-34.

Dalgalarrondo S and Hauray B (2015b) Les économies de la promesse anti-âge. Le cas de la DHEA. Sciences Sociales et Santé 33(2): 5-30.

Fahy GM (1995) DHEA in the spotlight: Part 2 of our exclusive meeting report on DHEA and aging. Life Extension Magazine, December, 10-12.

Fishman JR, Binstock RH and Lambrix MA (2008) Anti-aging science: The emergence, maintenance, and enhancement of a discipline. Journal of Aging Studies 22(4): 295-303.

Foucault M (2009) Le courage de la vérité-Le gouvernement de soi et des autres. Cours au Collège de France, 1984. Paris: Gallimard.

Fox N and Ward K (2006) Health identities: From expert patient to resisting consumer. Health 10(4): 461-479.

Fox N, Ward K and O'Rourke A (2005) Pro-anorexia, weight-loss drugs and the Internet: An "antirecovery" explanatory model of anorexia. Sociology of Health \& Illness 27(7): 944-971.

Gieryn TF (1983) Boundary work and the demarcation of science from nonscience: Strains and interests in professional ideologies of scientists. American Sociological Review 48(6): 781-796.

Haber C (2004) Life extension and history: The continual search for the fountain of youth. Journals of Gerontology, Series A: Biological Sciences and Medical Sciences 59(6): 515-522.

Hedgecoe A and Martin P (2003) The drugs don't work. Social Studies of Science 33(3): 327-364.

Katz S (2002) Growing older without aging? Positive aging, anti-ageism, and anti-aging. Generations 25(4): 27-32.

Kitzinger J and Williams C (2005) Forecasting science futures: Legitimising hope and calming fears in the embryo stem cell debate. Social Science \& Medicine 61(3): 731-740.

Latour B and Woolgar S (1986) Laboratory Life: The Construction of Scientific Facts. Princeton, NJ: Princeton University Press.

Le Fur E (2010) Méfiance avec la DHEA. Ouest France, 1 October, 1.

Marks H (1997) The Progress of Experiment: Science and Therapeutic Reform in the United States, 1900-1990. Cambridge: Cambridge University Press.

Moreira T and Palladino P (2005) Between truth and hope: On Parkinson's disease, neurotransplantation and the production of the "self." History of the Human Sciences 18(3): 55-82.

Mykytyn CE (2008) Medicalizing the optimal: Anti-aging medicine and the quandary of intervention. Journal of Aging Studies 22(4): 313-321.

Mykytyn CE (2010) A history of the future: The emergence of contemporary anti-ageing medicine. Sociology of Health \& Illness 32(2): 181-196.

Nelkin D (1987) Selling Science: How the Press Covers Science and Technology. New York: W. H. Freeman.

Newman TB (2003) The power of stories over statistics. British Medical Journal 327(7429): $1424-1427$.

Novas C (2006) The political economy of hope: Patients' organizations, science and biovalue. Biosocieties 1(3): 289-305. 
Petersen A (2015) Hope in Health. London: Palgrave Macmillan.

Petersen A and Seear K (2011) Technologies of hope: Techniques of the online advertising of stem cell treatments. New Genetics and Society 30(4): 329-346.

Petersen A and Wilkinson I (2015) Editorial introduction: The sociology of hope in contexts of health, medicine, and healthcare. Health 19(2): 113-118.

Porter T (1995) Trust in Numbers: The Pursuit of Objectivity in Science and Public Life. Princeton, NJ: Princeton University Press.

Prosser H (2010) Marvelous medicines and dangerous drugs: The representation of prescription medicine in the UK newsprint media. Public Understanding of Science 19(1): 52-69.

Regelson W and Colman C (1997) The Superhormone Promise. New York: Pocket.

Rubin B (2008) Therapeutic promise in the discourse of human embryonic stem cell research. Science as Culture 17(1): 13-27.

Rutkowski K, Sowa P, Rutkowska-Talipska J, et al. (2014) Dehydroepiandrosterone (DHEA): Hypes and hopes. Drugs 74(11): 1195-1207.

Ryle G (1968) The thinking of thoughts. What is "Le Penseur" Doing? In: Ryle G (ed.) Collected Essays. Oxon and New York: Routledge, pp. 494-510.

Seale C (2003) Media and health. 1st ed. London: SAGE.

Selin C (2007) Expectations and the emergence of nanotechnology. Science, Technology \& Human Values 32(2): 196-220.

Shapin S (1994) A Social History of Truth. Chicago, IL: Chicago University Press.

Stewart P (2006) Aging and fountain-of-youth hormones. New England Journal of Medicine 355(16): 1724-1726.

Stuckelberger A (2008) Anti-Ageing Medicine: Myths and Chances. Zürich: Vdf Hochschulverlag AG.

Thoër C and Lévy JJ (eds) (2012) Internet et santé, usages, acteurs et appropriations. Québec City, QC, Canada: Presses de l'Université du Québec.

Timmermans S and Berg M (2003) The Gold Standard: The Challenge of Evidence-Based Medicine and Standardization in Health Care. Philadelphia, PA: Temple University Press.

Tone A (2012) The Age of Anxiety: A History of America's Turbulent Affair with Tranquilizers. New York: Basic Books.

Vincent JA (2006) Ageing contested: Anti-ageing science and the cultural construction of old age. Sociology 40(4): 681-698.

\section{Author biographies}

Boris Hauray is a sociologist at the Institute for Interdisciplinary Research on Social Issues (IRIS) and researcher at the National Institute of Health and Medical Research (INSERM). He has worked on public health for more than 15 years and more particularly on the development of medicines and their control. He has published widely on these issues, including two books: Santé publique, l'état des savoirs, (co-edited with Didier Fassin, La Découverte, 2010); L'Europe du médicament (Presses de Sciences Po, 2006).

Sébastien Dalgalarrondo is a sociologist and researcher at the French National Center for Scientific Research (CNRS). He is the author of numerous publications on pharmaceutical innovation. His work considers medicines both as a scientific object and as a commercial product, infused with therapeutic promises. More specifically, his work has focused on treatments for AIDS (on which he has published Sida: la course aux molécules, Editions EHESS, 2004), cancer, rare diseases, and more recently aging. 